\title{
Fire-fallow agriculture as a sustainable cropping system for maintaining organic carbon in Maré Loyalty Island (New Caledonia, southwest Pacific)
}

\author{
Audrey Leopold $^{1}$ (D) $\cdot$ Julien Drouin ${ }^{1} \cdot$ Elia Drohnu ${ }^{1} \cdot$ Hélène Kaplan $^{1} \cdot$ Jacques Wamejonengo $^{1} \cdot$ Severine Bouard $^{2}$
}

Received: 18 July 2020 / Accepted: 14 July 2021 / Published online: 12 October 2021

(C) The Author(s) 2021

\begin{abstract}
The Loyalty Islands are part of the French archipelago of New Caledonia in the Southwest Pacific. In these islands, Gibbsic Ferralsols (Humic) are traditionally used for fire-fallow cultivation (FFC) by the Kanak people, but the planting of perennial orchards has been encouraged over the past two decades. The impacts of this policy on soil organic carbon (SOC) are nevertheless unknown, especially in these clay-free soils in which organic matter is the main contributor to soil fertility. SOC and permanganate oxidizable organic carbon (POXC) were studied in the soils of avocado orchards, FFC, and secondary and native forests. Mean SOC stocks are particularly high, ranging between 71.9 and $194.4 \mathrm{MgC} \mathrm{ha}^{-1}$ in an equivalent soil mass of $2000 \mathrm{Mg} \mathrm{ha}^{-1}$, but they are significantly impacted by land use. Avocado farming reduced SOC stocks by about $30 \%$ compared to forest soils, even if fields were established on secondary forests that had already experienced SOC losses. In contrast, FFC did not impact them. The POXC content decreased as the degree of soil anthropization increased; however, it was less sensitive than SOC in highlighting the impacts of land use. SOC storage can be achieved through changes in agricultural practices in avocado farming, with support for farmers in transitioning from family farming to perennial cultivation and the policy management of secondary forests designed to enhance the recovery of native forests.
\end{abstract}

Keywords Fire-fallow cultivation · Gibbsic Ferralsol $\cdot$ POXC · Soil organic carbon stock · Southwest Pacific Island

\section{Introduction}

Soils represent a large stock of carbon on a global scale storing more than $2500 \mathrm{GtC}$, mostly in organic carbon form (Lal 2004). Furthermore, soil respiration is one of the main means of natural carbon exchange between terrestrial ecosystems and the atmosphere (Le Quéré et al. 2018; Schlesinger and

Communicated by Beverley Henry and accepted by Topical Collection Chief Editor Christopher Reyer

This article is part of the Topical Collection on Regional management practices with positive effects on soil carbon to meet the goals of the 4 p1000 initiative

Audrey Leopold

leopoldaudrey@gmail.com

1 Équipe SolVeg, Institut Agronomique néo-Calédonien, 98848 Nouméa, New Caledonia

2 Équipe Terau, Institut Agronomique néo-Calédonien, 98825 Pouembout, New Caledonia
Andrews 2000). Small impacts on the quantity of soil carbon stored may therefore have major consequences on the global carbon cycle, with repercussions on global change. Increases in SOC might partially offset anthropogenic greenhouse gas (GHG) emissions (Paustian et al. 2016; Smith et al. 2018). Soils, and more specifically agricultural soils, could prove to be an effective and cheap solution for climate change mitigation that can be implemented within a short time frame but on a large spatial scale. To this end, the French government has launched the 4p1000 initiative, suggesting that an increase of $4 \%$ of the SOC stock would remove a significant proportion of carbon dioxide $\left(\mathrm{CO}_{2}\right)$ from the atmosphere, thereby partially mitigating anthropogenic GHG emissions (Minasny et al. 2017; Rumpel et al. 2018, 2019). Agriculture, forestry, and other land use (AFOLU) activities represent a large source of GHGs, especially because of deforestation. Some 23\% (12.0 $\pm 2.9 \mathrm{GtCO}_{2}$ eq year ${ }^{-1}$ ) of total net anthropogenic GHG emissions is related to AFOLU activities, which accounted for $13 \%$ of global $\mathrm{CO}_{2}$ emissions, $44 \%$ of methane emissions, and $81 \%$ of nitrous oxide emissions from human activities from 2007 to 2016 (IPCC 2019). On the other hand, the 
conversion from natural to agricultural ecosystems leads to a decrease of $75 \%$ in the SOC pool in some tropical soils (Lal 2004).

SOC is largely used to monitor changes in soil carbon on a worldwide scale, although fractions able to respond quickly to soil management are more suitable as early indicators of changes in the soil carbon stabilization or mineralization processes (Haynes 2005). Particulate and light organic carbon, permanganate oxidizable carbon (POXC), and microbial biomass are used as measures of active organic matter, also termed biologically active organic matter or labile carbon, and would be able to provide an early indication of SOC changes. Of these methods, POXC has been described as a carbon fraction sensitive to soil management, and its development could be favored because it is simple, rapid, and inexpensive (Culman et al. 2012). Having access to tools to detect changes at an early stage and adapt them to a broader audience represents an important lever for the management of carbon in soils. Farmers own the land and are key stakeholders in offsetting anthropogenic GHG emissions through their soil management choices. Another argument for farmers is to consider that increasing SOC stocks would also improve soil quality and agriculture production thanks to the role of soil organic matter (SOM) in the biological, physical, and chemical functioning of the soil (Lal 2016, 2020). Regional approaches seem to be appropriate, as farmers will apply management practices aimed at increasing SOC stocks if they have clear benefits in terms of yields, production costs, or the sustainability of their farm.

Family farms produce over $80 \%$ of food worldwide (FAO 2014) and manage 53\% of agricultural land (Graeub et al. 2016). Moreover, small-scale family farming is important in the countries of the South, both as a social fabric and as a means of supplying their markets (Bélières et al. 2014; Bouard et al. 2018). Fire-fallow or slash-and-burn agriculture is a system in which the native vegetation is slashed and burned before crops are farmed. After the harvest, the land is left fallow, and the cycle can be repeated. Burnt vegetation releases nutrients available for farming. These nutrients will be exported with the harvest, but the fallow period following this is a key factor for recovering soil health over time (Hauser and Norgrove 2013).

In the Loyalty Islands, the Kanak people have historically practiced fire-fallow agriculture on a family scale (Barrau 1956; Sand et al. 2000). Low burning is practiced on Gibbsic Ferralsol in forests; yam is grown the first year, while vegetables and fruits may be cultivated for 1 or 2 years before a fallow period sometimes lasting as long as 30 years. However, societal transformations in Maré have led to changes in agricultural practices. On the one hand, the emigration of young people to study or work, either for few years or permanently, has limited the labor force available for FFC. On the other hand, the development of orchards has been encouraged by financial support organizations. The impacts of these changes on SOM are nevertheless unknown. Generally speaking, SOC stocks in New Caledonia are not monitored, either in natural or in cultivated soils, and the impacts of agriculture on these soils are not analyzed. We hypothesize that in Maré, the shift in farming systems from a family and non-market model toward a more market-oriented one impacts SOC content by modifying agricultural practices. Our study aims to evaluate the impact of land use changes on SOC in Gibbsic Ferralsols by measuring the amount of organic carbon stored in these soils occupied by avocado orchards, fallow land, or forests, the main types of land use in Maré, and by evaluating the resulting changes in the POXC active carbon fraction.

\section{Material and methods}

\section{Study site and agricultural typology}

The study was conducted on Maré Island $\left(21^{\circ} 31^{\prime} 00^{\prime \prime} \mathrm{S} ; 167^{\circ}\right.$ $59^{\prime} 00^{\prime \prime} \mathrm{E}$ ), located in the Coral Sea (Southwest Pacific, New Caledonia). The Loyalty Islands are uplifted coral atolls sitting on volcanic bedrock. Based on pedological studies (Latham and Mercky 1981; Tercinier 1963, 1971) and on the World Reference Base classification (2006), Fritsch (2012) described three main types of soil: Lithic Leptosol, Haplic Cambisol, and Gibbsic Ferralsol. The last two of these have a remarkably high organic matter content (humic soils). The mineralogy of these ferralsols is dominated by iron and aluminum (Al) oxides. Al-oxide content represents more than $25 \%$ of the fine earth fraction. These soils do not contain phyllosilicate, and the SOM represents the main actor of the soil's cation retention capacity (Becquer et al. 2001; Duwig 1998). The $\mathrm{pH}$ values are neutral to slightly basic, total phosphorus is high $(>2 \%)$, but exchangeable phosphorus is insignificant. Moreover, exchangeable calcium and magnesium are high in the humic horizon, while potassium is deficient (Latham and Mercky 1981). These soils are decarbonated, even if very small traces of carbonates of recent biological origin may be found. On average, these ferralsols are thin (depth of $\sim 40 \mathrm{~cm}$ ) (Becquer et al. 1993), but are largely used for agriculture, especially family farming.

Mare is a small island $\left(641.7 \mathrm{~km}^{2}\right)$ with a low population density (9 inhabitants $\mathrm{km}^{-2}$ ) (ISEE 2019). In 2010, Kanak families from Maré produce $1940 \mathrm{t}$ of tubers, $240 \mathrm{t}$ of bananas, and $640 \mathrm{t}$ of fruit (including avocados), i.e., $18 \%, 4 \%$, and $13 \%$ respectively of Kanak small-scale family farming production (Guyard et al. 2014). Family farming takes the form of FFC based on yam farming. Yam is systematically planted in a new field, and the average fallow time is about 10 years but can exceed 30 years. Understory vegetation and the smallest trees are manually cut back. These slashes are left to dry and are then burned. Fires are also made at the foot of the trees 
when they were cut down. After yam cultivation, sweet potatoes, other vegetables, and fruits may be cultivated. This cultivation cycle could last 1 or 2 years, and the field is then left fallow (Barrau 1972). Cultivation is mainly practiced in a few known historical areas. Avocado farming here is non-intensive. After the forest is cleared, the biomass is generally pulled out of the field; trees are planted without the soil being tilled, even if some of them can be initially established in low ridges. The ground is generally grassed over but there is no understory under the avocado trees. Trees may be lightly pruned and pruning residues are left on the ground. Orchards are generally rain-fed and fertilizers or amendments are no longer used, even though fertilizers and chemicals may have been used when the orchard was first established.

\section{Sampling design}

Eleven study sites in four locations were chosen, based on land use and soil occupation: avocado orchard, FFC, and forest (Fig. 1). FFC fields were selected based on a fallow period of fewer than 10 years. For each cultivated field (avocado and FFC), we also sampled the soil in the nearest neighboring forest. Native forests are moist, dense evergreen forests; however, because of anthropogenic disturbances, the nearest neighboring forests - notably for avocado fields - may be secondary forests in which exotic flora has developed (Morat et al. 2001). We assumed that the current status of the closest neighboring forests was representative of the initial state before avocado cultivation.
In each location, five cores were taken with an inox core sampler. Cores were cut in the field $(0-5 \mathrm{~cm}, 5-10 \mathrm{~cm}, 10$ $20 \mathrm{~cm}$, and $20-30 \mathrm{~cm}$ ), and each part was put in an individual bag and brought to the laboratory in an icebox. They were kept in a cold room $\left(+4{ }^{\circ} \mathrm{C}\right)$ in darkness before their preparation for laboratory analysis.

\section{Soil preparation and laboratory analysis}

After air-drying to obtain constant mass and weighing, samples were individually sieved at $2 \mathrm{~mm}$; coarse fractions were removed by hand and weighed to estimate their contribution and to assess the percentage of fine earth in each depth. Subsamples of air-dried fine earth were weighed, and ovendried at $105^{\circ} \mathrm{C}$ to evaluate the residual mass of water arising from the air-drying process. For the SOC and POXC analyses, 2-mm air-dried soils were crushed and sieved to $0.1 \mathrm{~mm}$. The modified Walkley and Black method (1934) was used to determine the content of soil organic carbon $\left(\mathrm{SOC}_{(\mathrm{WB})}\right)$ in all samples. Briefly, $0.1 \pm 0.001 \mathrm{~g}$ of soil is mixed with $10 \mathrm{~mL}$ of dichromate solution (3\%) and $7.5 \mathrm{~mL}$ of concentrated $\mathrm{H}_{2} \mathrm{SO}_{4}$. This mixture is heated at $135{ }^{\circ} \mathrm{C}$ for $30 \mathrm{~min}$. After cooling and addition of deionized water, the organic carbon content was measured by means of a flow injection analyzer (AutoAnalyzer $3 \mathrm{HR}$, SEAL) coupled with spectrophotometric analysis at $550 \mathrm{~nm}$. Because this method may underestimate the content of SOC, especially when the content of organic matter is high, we also measured the soil carbon content resulting from the dry combustion method $\left(\mathrm{SOC}_{(\mathrm{DC})}\right)$, as well
Fig. 1 Map of the New Caledonia archipelago and soil map of Maré Island (modified from Fritsch, 2012). The sampling locations are shown on the map of Maré Island: Tadurehmu, Taodé, Atha, and Tawaïnèdre

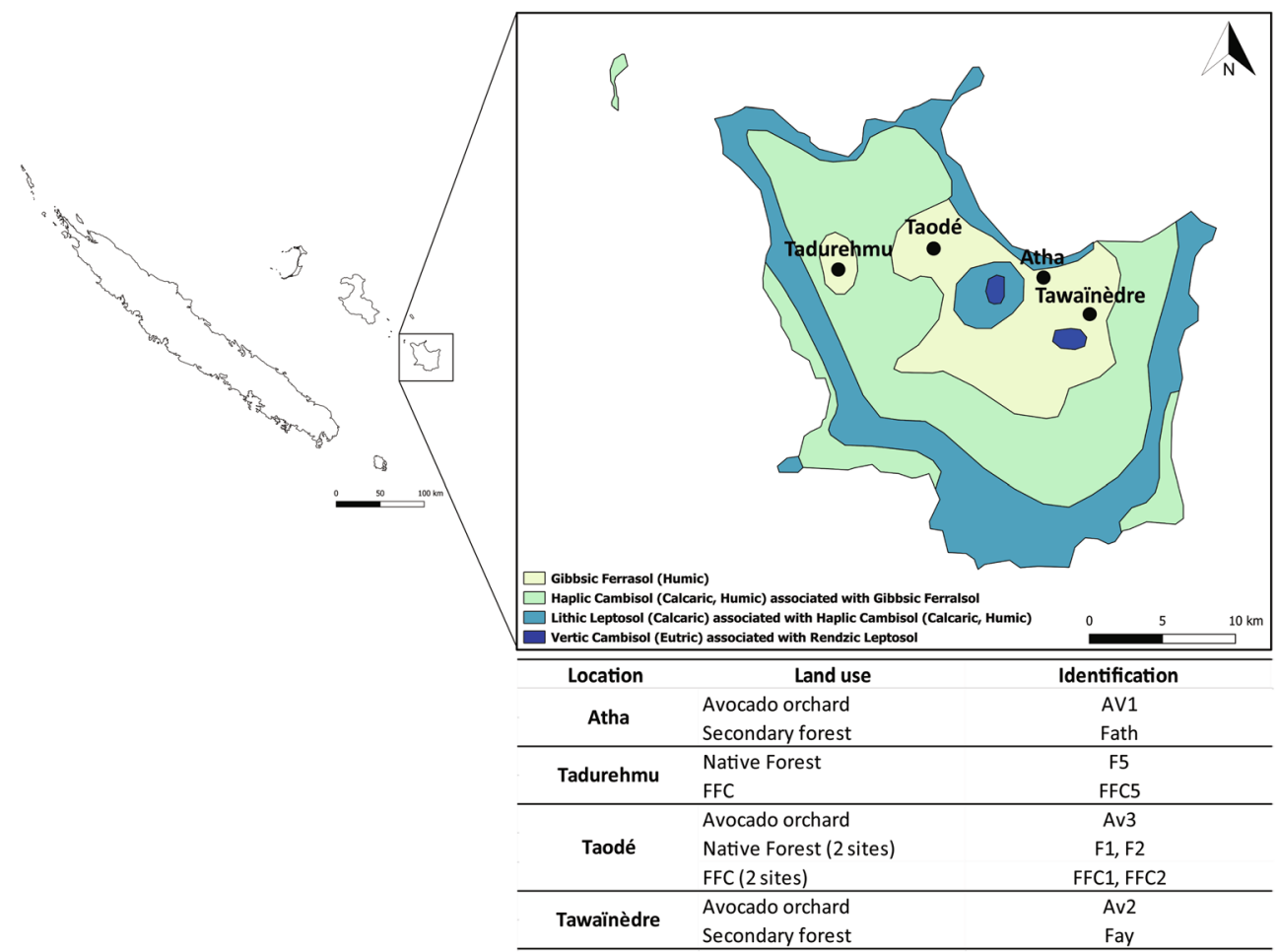


as ${ }^{13} \mathrm{C}$ of SOC, using an elemental analyzer-IRMS (Integra 2, Sercon) in all samples of two cores from each location sites ( $n$ $=88$ ). Total carbon content was considered organic carbon content because these soils do not contain significant quantities of carbonates. The linear relationship between $\mathrm{SOC}_{(\mathrm{WB})}$ and $\mathrm{SOC}_{(\mathrm{DC})}$ was very good $\left(\mathrm{lm}, R^{2}=0.9908, P<2.2 \times\right.$ $10^{-16}$ ), with $\mathrm{SOC}_{(\mathrm{WB})}$ accounting for $93 \%$ of $\mathrm{SOC}_{(\mathrm{DC})}$ (Fig. 2A). We are highly confident in the organic carbon data obtained by means of wet combustion in our study, and to avoid adding errors, we used $\mathrm{SOC}_{(\mathrm{WB})}$ values without a correction factor. The concentration of $\mathrm{POXC}$ was determined by the reaction of a known mass of soil with a diluted potassium permanganate solution (Weil et al. 2003). In total, $0.75 \mathrm{~g} \pm$ $0.02 \mathrm{~g}$ of soil was brought into contact with $20 \mathrm{~mL}$ of $\mathrm{KMnO}_{4}$ $\left(0.02 \mathrm{~mol} \mathrm{~L}^{-1}\right)$, shaken at $120 \mathrm{rpm}$ for exactly $2 \mathrm{~min}$ and left to settle in the dark for exactly 10 min (Wade et al. 2020). After settling and dilution, the absorbance of each sample was read by using a spectrophotometer (Evolution 201, Thermo Scientific) at $550 \mathrm{~nm}$. Every tenth sample, a standard soil sample $\left(1199 \pm 114 \mathrm{mgPOXC} \mathrm{kg}^{-1}\right.$ dry soil, $17.99 \pm 0.34 \mathrm{gC}$
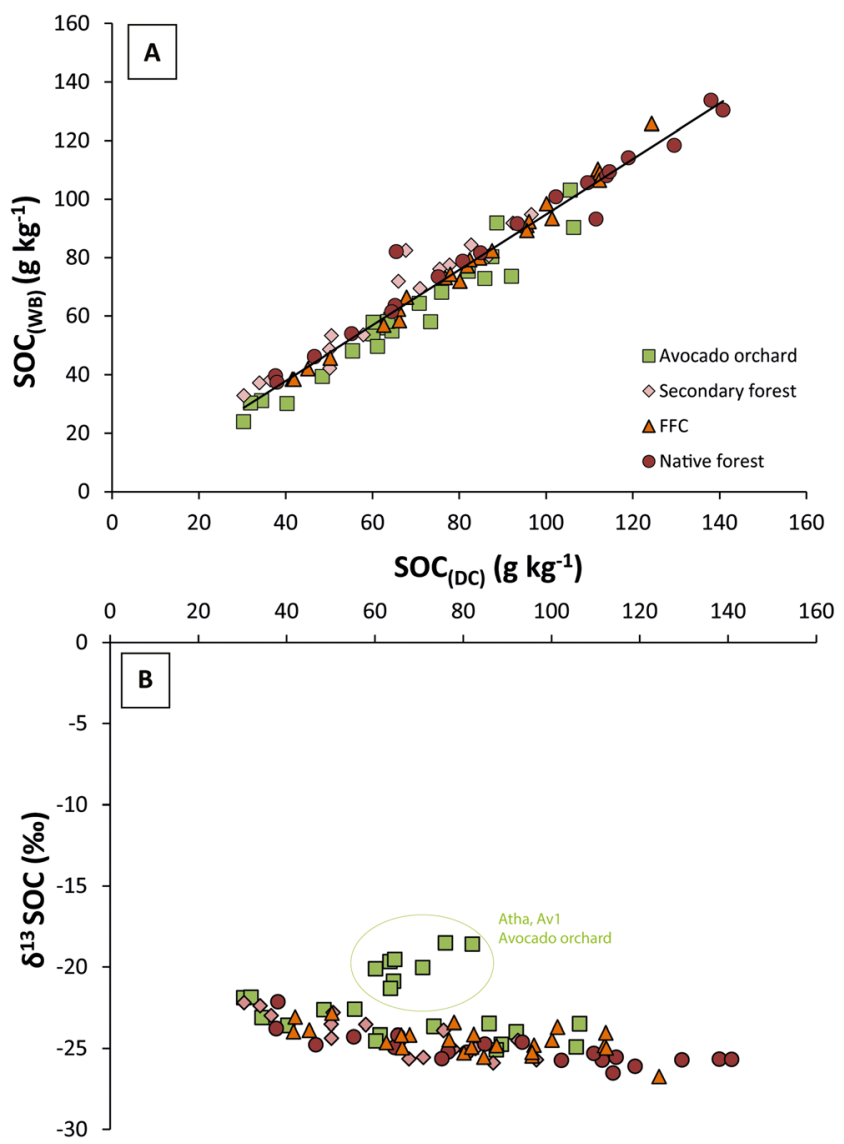

Fig. 2 Soil organic carbon (SOC) measured with the modified Walkley and Black method $\left(\mathrm{SOC}_{(\mathrm{WB})}, \mathrm{g} \mathrm{kg}^{-1}\right.$ ) versus $\mathrm{SOC}$ measured with the dry combustion method $\left(\mathrm{SOC}_{(\mathrm{DC})}, \mathrm{g} \mathrm{kg}^{-1}\right)$. All four sampled depths of two cores from each site were analyzed. The linear relationship between $\mathrm{SOC}_{(\mathrm{WB})}$ and $\mathrm{SOC}_{(\mathrm{DC})}$ was particularly good $\left(\mathrm{lm}, R^{2}=0.9908, p\right.$-val$\left.\mathrm{ue}<2.2 \times 10^{-16}\right)$, and $\mathrm{SOC}(\mathrm{WB})$ was $93 \%$ of $\operatorname{SOC}_{(\mathrm{DC})}(\mathbf{A})$. Variation of $\delta^{13} \mathrm{C}$ of $\mathrm{SOC}$ versus $\mathrm{SOC}_{(\mathrm{DC})}\left(\mathrm{g} \mathrm{kg}^{-1}\right)(\mathbf{B})$ $\mathrm{kg}^{-1}$ dry soil) was measured as a reference for assessing the reproducibility of the method. The POXC was calculated as in Weil et al.'s work (2003) (Eq. 1).

$\mathrm{POXC}=\frac{\left[\left[C_{\mathrm{KMnO}_{4}}-\left(a+\left(b \times A b s_{a d j}\right)\right)\right] \times\left(M_{\mathrm{Cox}} \times\left(V_{\mathrm{KMnO} 4}\right)\right)\right]}{\mathrm{Wt}}$

where $\mathrm{POXC}$ is the concentration of oxidizable organic carbon by $\mathrm{KMnO}_{4}\left(\mathrm{mg} \mathrm{kg}^{-1}\right.$ dry soil $) ; C_{\mathrm{KMnO}}$, the initial solution concentration of $\mathrm{KMnO}_{4}\left(0.02 \mathrm{~mol} \mathrm{~L}^{-1}\right) ; a$, the intercept of the standard curve; $b$, the slope of the standard curve; $A b s_{a d j}$, the adjusted absorbance of the unknown soil sample; $M_{\mathrm{Cox}}$, the mass of carbon oxidized by 1 mol of $\mathrm{MnO}_{4}$ changing from $\mathrm{Mn}^{7+}$ to $\mathrm{Mn}^{4+}\left(9000 \mathrm{mgC} \mathrm{mol}^{-1}\right), V$, the volume of $\mathrm{KMnO}_{4}$ solution used $(0.02 \mathrm{~L})$; and $\mathrm{Wt}$, the weight of the air-dried soil sample $(0.00075 \mathrm{~kg})$.

\section{Carbon stock calculation based on the equivalent soil mass approach}

To avoid bias in SOC stock calculations related to changes in bulk density, SOC stocks were measured based on an equivalent soil mass approach. The mass of the fine earth fraction and organic carbon was determined in each depth sampled in each core (Eqs. 2 and 3), as described in Wendt's and Hauser's study (2013). The cumulative soil and OC masses were calculated by summing their respective depth layer masses, calculated in Eqs. (2) and (3) to any given depth. SOC stock was then computed in $2000 \mathrm{Mg} \mathrm{ha}^{-1}$, i.e., the soil mass average in the $00-30-\mathrm{cm}$ soil layer, using the cubic spline function in the R software (v.3.6.3).

$$
\begin{aligned}
M_{\text {soil }(\mathrm{DL})} & =\frac{M_{\text {sample(DL) }}}{\text { Area sampled }} \times 10,000 \\
M_{\mathrm{OC}(\mathrm{DL})} & =M_{\text {soil }(\mathrm{DL})} \times C_{\mathrm{OC}(\mathrm{DL})}
\end{aligned}
$$

where $M_{\mathrm{OC}(\mathrm{DL})}$ is the mass of organic carbon in the depth layer $\left(\mathrm{kg} \mathrm{ha}^{-1}\right) ; M_{\text {soil(DL) }}$ the mass of soil $<2 \mathrm{~mm}$ in each depth layer (DL) $\left(\mathrm{Mg} \mathrm{ha}^{-1}\right)$ and $C_{\mathrm{OC}(\mathrm{DL})}\left(\mathrm{g} \mathrm{kg}^{-1}\right)$ the concentration of organic carbon in the depth layer $\left(\mathrm{g} \mathrm{kg}^{-1}\right)$.

\section{Statistical analyses}

Variations of SOC or POXC with depth and land use type, and variations of SOC stocks with land use type were studied by means of ANOVA tests checking condition applications (homoscedasticity of variances and normality) and using Tukey's test as a post hoc test. Comparisons of SOC stocks per land use type for each location studied were performed using the Mann-Whitney or Kruskal-Wallis tests. In the latter case, Conover's tests were conducted to highlight differences. The relationship between SOC and POXC was studied by means of linear regression considering all datasets and for each type of land use. Analysis of covariance made it possible to assess statistical differences between slopes of 
the linear models estimated. All statistical analyses were performed using the R software (v.3.6.3).

\section{Results}

\section{Total and labile soil organic carbon}

$\delta^{13} \mathrm{C}$ values measured on SOC ranged from -26.7 and $-18.6 \%$, and tended to decrease as SOC increased (Fig. 2B). In the 0-30$\mathrm{cm}$ soil layer, mean ${ }^{13} \mathrm{C}$ values were $-20.0 \pm 0.7 \%$ o, $-24.5 \pm$ $1.1 \%$ and $-24.6 \pm 0.6 \%$ for Atha avocado orchards, Atha (secondary) forests, and Taodé (native) forests, respectively. SOC was significantly enriched in ${ }^{13} \mathrm{C}$ in the Atha avocado orchard compared to the other values (Av1, Fig. 2B). Moreover, mean ${ }^{13} \mathrm{C}$ values tended to increase with depth in forest and FFC soils, as well as in the Tawaïnèdre and Taodé orchards, whereas they decreased with depth in the Atha avocado orchard (SI 1).

SOC concentrations ranged from 19.4 to $149.2 \mathrm{~g} \mathrm{~kg}^{-1}$ (Table 1), and more than $60 \%$ of the samples displayed a SOC concentration greater than $60 \mathrm{~g} \mathrm{~kg}^{-1}$. The lowest mean concentrations of SOC, i.e., $37.4 \pm 15.2 \mathrm{~g} \mathrm{~kg}^{-1}$ and $36.2 \pm$ $8.1 \mathrm{~g} \mathrm{~kg}^{-1}$, were measured in the $20-30-\mathrm{cm}$ depth layer in avocado orchards and secondary forests respectively (Table 1). In contrast, the highest mean concentration of SOC, i.e., $121.6 \pm 15.8 \mathrm{~g} \mathrm{~kg}^{-1}$ was measured in the $00-05-$ $\mathrm{cm}$ soil layer of native forests (Table 1). SOC concentrations decreased significantly from the soil surface to a depth of $30 \mathrm{~cm}$ (aov, $P<0.001$ ) (Fig. 3). This trend was similar for all plots studied, except the Atha orchard in which mean SOC concentrations were only higher in the 00-05 cm layer (aov, $P$ $<0.001$ ) (Fig. 3). The impact of land use on SOC concentrations was more pronounced in the shallower soil layers than in the 20-30 cm layer (Table 1). Thus, in the 00-20 cm layer, mean SOC concentrations increased significantly with the following sequence (aov, $P<0.001$ ): avocado orchard $61.3 \pm$ $7.6 \mathrm{~g} \mathrm{~kg}^{-1}<$ secondary forest $69.8 \pm 9.4 \mathrm{~g} \mathrm{~kg}^{-1}<$ FFC 81.9 $\pm 14.5 \mathrm{~g} \mathrm{~kg}^{-1}<$ native forest $89.9 \pm 15.2 \mathrm{~g} \mathrm{~kg}^{-1}$. While mean SOC concentrations in the avocado orchards and secondary forests did not differ for the overall soil profile $(00-30 \mathrm{~cm})$, they were significantly lower than mean SOC concentrations in both FFC and native forest (data not shown).

POXC values presented a wide variation ranging from a minimum of $836 \mathrm{mg} \mathrm{kg}^{-1}$ (20-30 $\mathrm{cm}$ depth, avocado orchard) to a maximum of $4507 \mathrm{mg} \mathrm{kg}^{-1}$ (00-05 $\mathrm{cm}$ depth, native forest) (Table 1). The lowest mean concentrations of POXC, i.e., $1319 \pm 324 \mathrm{mg} \mathrm{kg}^{-1}$ and $1386 \pm 451 \mathrm{mg} \mathrm{kg}^{-1}$, were measured in the $20-30-\mathrm{cm}$ depth layer in avocado orchards and secondary forests respectively (Table 1), while the 00-05$\mathrm{cm}$ soil layer of native forest displayed the highest mean POXC, i.e., $3828 \pm 398 \mathrm{mg} \mathrm{kg}^{-1}$ (Table 1). As described for SOC, POXC decreased significantly with depth (aov, $P$ $<0.001)$. POXC concentrations in the $20-30-\mathrm{cm}$ soil layer were lower than in the other soil layers but did not differ
Table 1 Mean, standard deviation (sd), minimum (Min.) and maximum (Max.) values of soil organic carbon ( $\mathrm{SOC}, \mathrm{g} \mathrm{kg}^{-1}$ ) and soil permanganate oxidizable carbon (POXC, $\mathrm{mg} \mathrm{kg}^{-1}$ ) as a function of soil depth layer $(00$ $05 \mathrm{~cm}, 05-10 \mathrm{~cm}, 10-20 \mathrm{~cm}, 20-30 \mathrm{~cm}$ ) and land use type (avocado orchard, fire-fallow cultivation system (FFC), secondary and native forests). Different letters represent significant differences at the $P<0.05$ probability level

\begin{tabular}{|c|c|c|c|c|c|c|c|c|c|c|c|}
\hline & & \multicolumn{5}{|c|}{$\mathrm{SOC}\left(\mathrm{g} \mathrm{kg}^{-1}\right)$} & \multicolumn{5}{|c|}{ POXC (mg kg $\left.{ }^{-1}\right)$} \\
\hline & & Mean & $\mathrm{sd}$ & - & Min. & Max. & Mean & sd & - & Min. & Max. \\
\hline \multirow[t]{4}{*}{ Avocado orchard } & $00-05 \mathrm{~cm}$ & 79.6 & 13.0 & $a b c$ & 58.1 & 103.1 & 3053 & 472 & $\mathrm{a}$ & 2443 & 4000 \\
\hline & $05-10 \mathrm{~cm}$ & 67.3 & 10.1 & ad & 52.3 & 91.9 & 2475 & 390 & $\mathrm{bc}$ & 1916 & 3144 \\
\hline & $10-20 \mathrm{~cm}$ & 50.8 & 10.4 & $\mathrm{e}$ & 32.3 & 66.6 & 1924 & 328 & def & 1309 & 2456 \\
\hline & $20-30 \mathrm{~cm}$ & 37.4 & 15.2 & $\mathrm{e}$ & 19.4 & 60.5 & 1386 & 451 & def & 836 & 2967 \\
\hline \multirow[t]{4}{*}{ Secondary forest } & $00-05 \mathrm{~cm}$ & 92.0 & 8.0 & $\mathrm{cf}$ & 82.5 & 106.1 & 3476 & 265 & $\mathrm{ag}$ & 2955 & 4290 \\
\hline & $05-10 \mathrm{~cm}$ & 76.0 & 10.2 & $\mathrm{ab}$ & 60.4 & 94.6 & 2946 & 116 & $\mathrm{ac}$ & 2595 & 3598 \\
\hline & $10-20 \mathrm{~cm}$ & 55.5 & 13.3 & de & 32.4 & 69.7 & 1979 & 407 & efh & 1230 & 2704 \\
\hline & $20-30 \mathrm{~cm}$ & 36.2 & 8.1 & $\mathrm{e}$ & 19.4 & 49.3 & 1319 & 324 & $\mathrm{~d}$ & 877 & 1780 \\
\hline \multirow[t]{4}{*}{ Fire-fallow cultivation system } & $00-05 \mathrm{~cm}$ & 102.1 & 22.3 & fg & 71.4 & 149.2 & 3471 & 420 & ag & 2793 & 4370 \\
\hline & $05-10 \mathrm{~cm}$ & 86.6 & 16.4 & bcf & 60.8 & 117.6 & 2993 & 399 & a & 2382 & 3883 \\
\hline & $10-20 \mathrm{~cm}$ & 69.4 & 11.7 & abd & 53.3 & 93.3 & 2379 & 362 & bh & 1744 & 2888 \\
\hline & $20-30 \mathrm{~cm}$ & 48.0 & 13.2 & $\mathrm{e}$ & 22.7 & 74.3 & 1672 & 422 & de & 955 & 2351 \\
\hline \multirow[t]{4}{*}{ Native forest } & $00-05 \mathrm{~cm}$ & 121.6 & 15.8 & g & 90.1 & 147.3 & 3828 & 398 & g & 3274 & 4507 \\
\hline & $05-10 \mathrm{~cm}$ & 96.8 & 18.1 & $\mathrm{cf}$ & 59.8 & 138.5 & 3064 & 391 & a & 2392 & 3849 \\
\hline & $10-20 \mathrm{~cm}$ & 70.5 & 15.9 & abd & 41.6 & 105.1 & 2358 & 509 & bfh & 1401 & 2966 \\
\hline & $20-30 \mathrm{~cm}$ & 48.3 & 12.2 & $\mathrm{e}$ & 32.8 & 76.7 & 1619 & 409 & de & 886 & 4459 \\
\hline
\end{tabular}


Fig. 3 Variation of soil organic carbon (SOC, $\mathrm{g} \mathrm{kg}^{-1}$ ) with soil depth $(\mathrm{cm})$. For each land use type, i.e., avocado orchards, firefallow cultivation system (FFC), and native (F1, F2, F5) and secondary (Fath, Fay) forests, average SOC values are presented for all sampled fields and in the middle of each soil layer studied, i.e., at $2.5 \mathrm{~cm}$ for the $00-05 \mathrm{~cm}$ soil layer, $7.5 \mathrm{~cm}$ for the $05-10-\mathrm{cm}$ soil layer, $15 \mathrm{~cm}$ for the 10-20$\mathrm{cm}$ soil layer, and $25 \mathrm{~cm}$ for the 20-30-cm layer). The horizontal bars represent the standard deviation (sd)

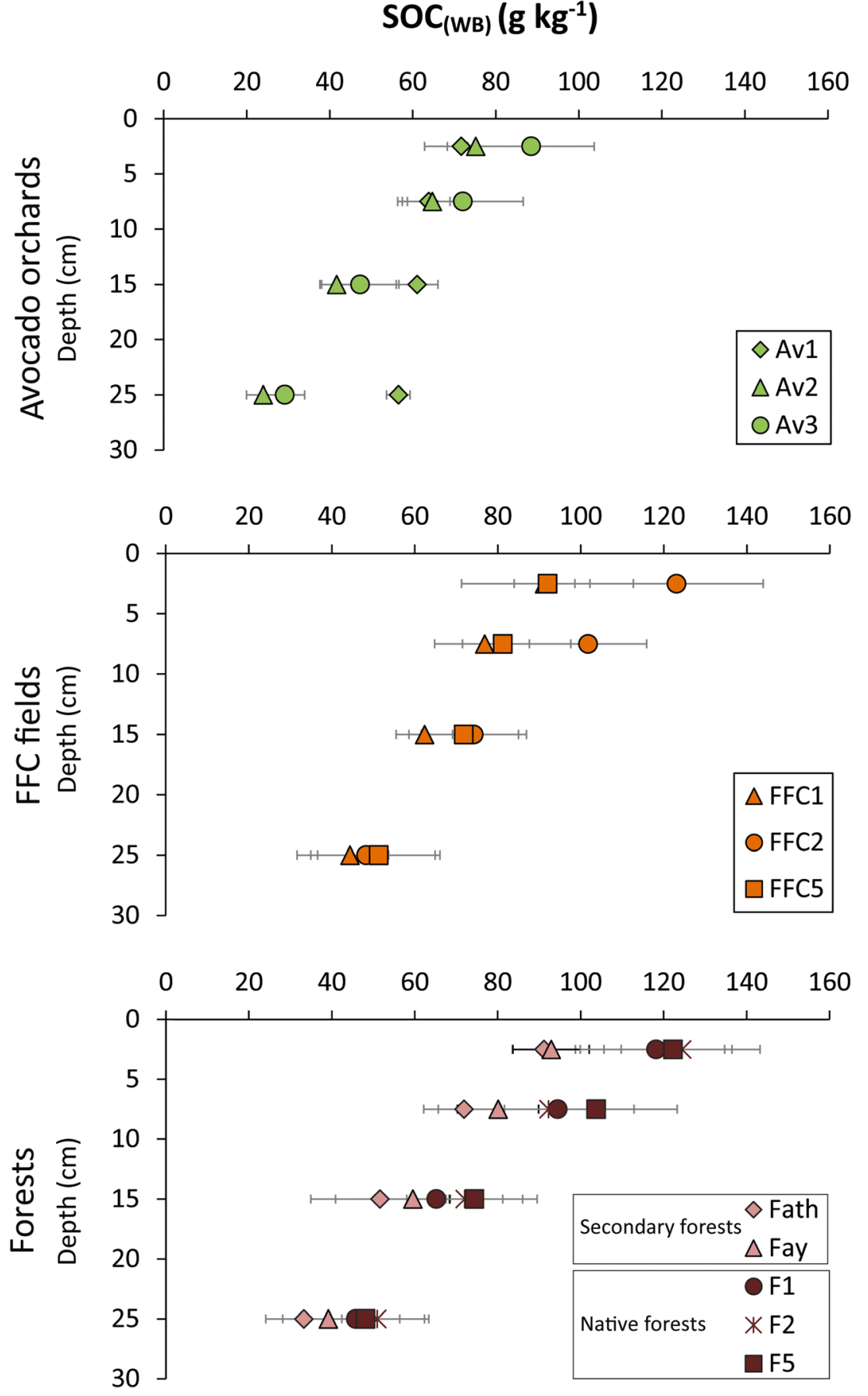

between land uses (Table 1). Moreover, the impact of land use on POXC in the shallower soil layers was less pronounced than for SOC concentrations. Thus, mean POXC concentrations in the 00-20-cm layer increased slightly in the following sequence: avocado orchard $2349 \pm 255 \mathrm{mg} \mathrm{kg}^{-1} \leq$ secondary forest $2595 \pm 285 \mathrm{mg} \mathrm{kg}^{-1}=$ FFC $2811 \pm 344 \mathrm{mg} \mathrm{kg}^{-1}=$ native forest $2911 \pm 391 \mathrm{mg} \mathrm{kg}^{-1}$. With regard to the overall soil profile $(00-30 \mathrm{~cm})$, mean $\mathrm{POXC}$ concentrations varied in the same way as SOC according to land use (not shown).
Considering all data, a positive and linear variation between SOC and POXC was highlighted $\left(l m, R^{2}=0.982, P\right.$ $<2.2 \times 10^{-16}$ ) (Fig. 4). However, for each type of land use, the slopes of the linear relationships decreased significantly in the following sequence: avocado orchard $\geq$ secondary forest $\geq$ fire-fallow cultivation system $>$ native forest, indicating a different contribution of POXC to SOC according to land use. POXC accounted for $3.799 \%, 3.731 \%, 3.388 \%$, and $3.172 \%$ of SOC from avocado orchards, secondary forests, FFC, and 


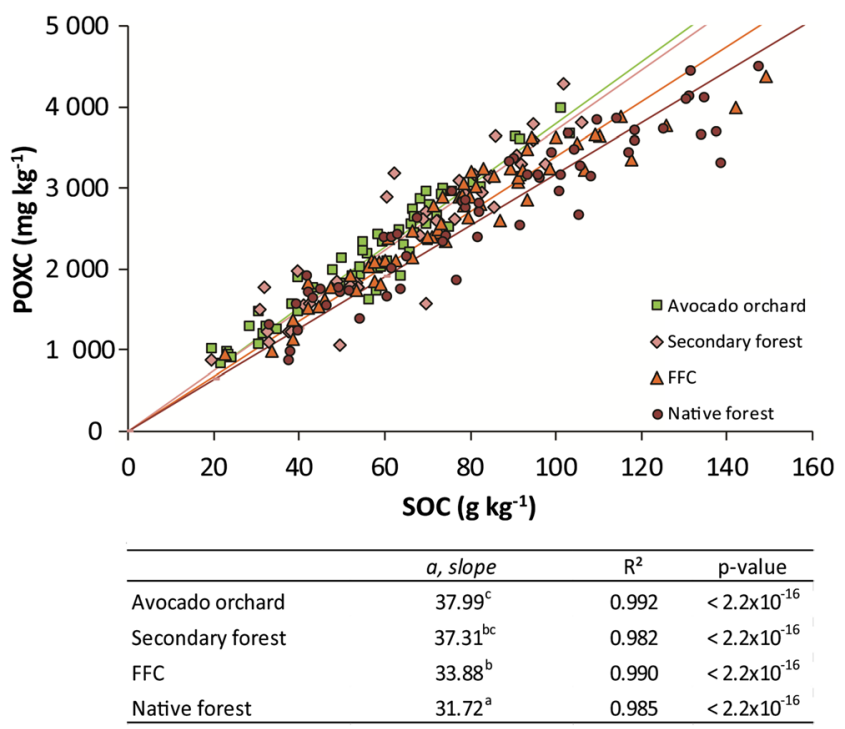

Fig. 4 Soil permanganate oxidizable carbon (POXC, $\mathrm{mg} \mathrm{kg}^{-1}$ ) as a function of soil organic carbon ( $\mathrm{SOC}, \mathrm{g} \mathrm{kg}^{-1}$ ) under the different land uses studied: avocado orchard (green square), secondary forest (pink diamond), fire-fallow cultivation system (FFC) (orange triangle), and native forest (red circle). Linear relationships are plotted for each land use type on the panel. Below the panel, the main parameters of these linear relationships are mentioned: slopes (a), $R^{2}$ and $p$-value. Considering the whole data set, the linear relationship between POXC and SOC is as follows: POXC $\left(\mathrm{mg} \mathrm{kg}^{-1}\right)=34.2728 \times \mathrm{SOC}\left(\mathrm{g} \mathrm{kg}^{-1}\right), R^{2}=$ $\left.0.982, P<2.2 \times 10^{-16}\right)$

native forests respectively (Fig. 4). If POXC contribution to SOC significantly varied with land use, it did not vary with depth (aov, $P>0.05$; data not shown). Moreover, considering the whole dataset, the contribution of POXC to SOC (\%) decreased slightly but significantly as SOC increased $(\mathrm{lm}$, $R^{2}=0.1561, P<0.001$, not shown).

\section{Soil organic carbon stocks according to land use}

SOC stocks assessed in $2000 \mathrm{Mg}$ ESM ranged from $71.9 \mathrm{MgC}$ $\mathrm{ha}^{-1}$ (avocado orchards) to $194.4 \mathrm{MgC} \mathrm{ha}^{-1}$ (native forests). Mean SOC stocks varied from 101.4 $\pm 20.4 \mathrm{MgC} \mathrm{ha}^{-1}$ in avocado orchards to $138.3 \pm 23.6 \mathrm{MgC} \mathrm{ha}^{-1}$ in native forests; they increased significantly in the following sequence: avocado orchard $\leq$ secondary forest $\leq$ fire-fallow cultivation system $\leq$ native forest (Table 2). At the Atha location, SOC stock in the avocado orchard increased by almost $20 \%$ compared with SOC stocks assessed in the neighboring secondary forest (Table 2). At the Tawaïnèdre and Taodé locations, SOC stocks were $\sim 30 \%$ lower in avocado orchards than in FFC, compared to SOC stocks in both native and secondary forests (Table 2). At the Tadurehmu and Taodé locations, although SOC stocks were slightly higher in forest soil compared to the FFC system, no significant statistical differences appeared (Table 2). Finally, SOC stocks assessed in the secondary forests at the Atha and Tawaïnèdre sites were $20 \%$ lower than stocks measured in the soils of native forests in the Taodé and Tadurehmu locations (Table 2).

\section{Discussion}

\section{High content of soil organic carbon in Maré Gibbsic Ferralsol}

Even in cultivated soils and in the $20-30-\mathrm{cm}$ soil layer, these Gibbsic Ferralsol have high SOC concentrations of up to $149.2 \mathrm{~g} \mathrm{~kg}^{-1}$ (Table 1), justifying their description as "humic" soils. Surprisingly, while the Loyalty Islands are formed on calcaric substrate, these soils would have developed from exogenous matter, notably volcanic ash and pumice (Tercinier 1954; Latham and Mercky 1981). Becquer et al. (2001) showed that the content of aluminum oxides in these soils represents more than $25 \%$ of fine fraction, with gibbsite as a major component of the crystalline fraction. Organo-mineral interactions, notably SOM sorption onto iron/aluminum oxides, increase the soil structure and aggregation, decrease the availability of SOM to microorganisms, and lead to SOC storage (Kleber et al. 2007; Mathieu et al. 2015; Moni et al. 2010; Wiesmeier et al. 2019). The high amount of SOM in these soils could be related to the strong binding of aluminum/iron compounds and organic substances (Becquer et al. 2001), as suggested indirectly by great difficulties in the digestion of organic matter with $\mathrm{H}_{2} \mathrm{O}_{2}$ (Latham and Mercky 1981). However, the key factors explaining these SOM contents remain largely unexplored.

\section{Relationships between soil organic carbon and permanganate oxidizable carbon}

Both SOC and POXC generally decreased as the degree of anthropization increased; i.e., they were lower in the soils of avocado orchards and higher in the soils of native forests. However, differences in land use were more pronounced for SOC than for POXC. Some authors have also shown that SOC, hot water extractable carbon, and fine particulate organic carbon are more sensitive to management practices compared to POXC (Duval et al. 2018; Jensen et al. 2020). POXC significantly and linearly varied with SOC as already described in various studies (Fig. 4) (Culman et al. 2012; Hurisso et al. 2016; Morrow et al. 2016; Skjemstad et al. 2006). This strong relationship is related to methodologies used to measure these parameters, i.e., partial or complete oxidation of total organic carbon by $\mathrm{KMnO}_{4}$ or by chromic acid (Culman et al. 2012). Higher POXC concentrations at the soil surface and in the less anthropized ecosystems (natural forests and FFC) indicate a higher content of easily oxidizable organic matter, suggesting higher microbial biomass and activity promoting long-term SOM stabilization in these weaklyor non-anthropized systems (Awale et al. 2017; Bongiorno et al. 2019; Culman et al. 2010, 2012; Melero et al. 2011). 
Table 2 Mean, standard deviation (sd), minimum (min.), and maximum (max.) soil organic carbon (SOC) stocks $\left(\mathrm{MgC} \mathrm{ha}_{-1}\right.$ in $2000 \mathrm{Mg}$ ha ${ }_{-1}$ equivalent soil mass) assessed in avocado orchards, secondary forests, fire-fallow cultivation system (FFC), and native forests. Different letters represent significant differences at the $P<0.05$ probability level. Mean and standard deviation of SOC stocks assessed in the different systems studied and by sampling location (Atha, Tawained, Taode, Tadurehmu).
For each site, mean differences in SOC stock ( $\triangle \mathrm{SOC}$ stock) were assessed between the cultivated and/or forest ecosystem, i.e., SOC stock in avocado orchard minus SOC stock in forest, SOC stock in avocado orchard minus SOC stock in FFC, or SOC stock in FFC minus SOC stock in forest. Different letters represent significant differences at the $P<0.05$ probability level. Ns indicates statistically insignificant differences

SOC stock $\left(\mathrm{MgC} \mathrm{ha}^{-1}\right)$ in $2000 \mathrm{Mg} \mathrm{ha}^{-1} \mathrm{ESM}$

\begin{tabular}{|c|c|c|c|c|c|c|c|}
\hline Location & Land use type & Mean & & Sd & Min. & Max. & \\
\hline \multirow[t]{6}{*}{ All } & Avocado orchard & 101.4 & $\mathrm{a}$ & 20.4 & 71.9 & 131.3 & \\
\hline & Secondary forest & 112.2 & $\mathrm{ab}$ & 13.5 & 88.7 & 134.3 & \\
\hline & FFC & 133.3 & $\mathrm{bc}$ & 22.2 & 109.2 & 179.6 & \\
\hline & Native forest & 138.3 & $\mathrm{c}$ & 23.6 & 103.3 & 194.4 & \\
\hline & & & & & & $\triangle \mathrm{SOC}$ stock & \\
\hline & & & & & Avocado - forest & Avocado - FFC & FFC - forest \\
\hline \multirow[t]{2}{*}{ Atha } & Avocado orchard & 123.8 & $\mathrm{~b}$ & 7.5 & $+19.6 \pm 6.5$ & & \\
\hline & Secondary forest & 104.2 & $\mathrm{a}$ & 12.4 & & & \\
\hline \multirow[t]{2}{*}{ Tawaïnèdre } & Avocado orchard & 81.9 & $\mathrm{a}$ & 7.5 & $-38.3 \pm 5.6$ & & \\
\hline & Secondary forest & 120.1 & $\mathrm{~b}$ & 9.9 & & & \\
\hline \multirow[t]{3}{*}{ Taodé } & Avocado orchard & 98.6 & $\mathrm{a}$ & 15.2 & $-39.2 \pm 11.2$ & $-33.2 \pm 9.7$ & \\
\hline & FFC & 131.8 & $\mathrm{~b}$ & 22.0 & & & $-5.9 \pm 11.3$ \\
\hline & Native forest & 137.8 & $\mathrm{~b}$ & 28.2 & & & \\
\hline \multirow[t]{2}{*}{ Tadurehmu } & FFC & 136.2 & ns & 24.9 & & & $-8.3 \pm 12.6$ \\
\hline & Native forest & 144.5 & & 13.4 & & & \\
\hline
\end{tabular}

Surprisingly, while the POXC and SOC relationship was particularly strong considering all data, the contribution of POXC to SOC did not vary with depth and varied significantly with land use. Except in the FFC soil layers, in which POXC may be lower depending on the charcoal content (Demisie et al. 2014), it could be expected that a higher labile carbon content be found in the topsoil compared to the subsoil because of higher fresh carbon inputs at the soil surface (Fontaine et al. 2007). Subsequently, the POXC/SOC ratio should decrease with depth, but this was not the case here. Recent or important root exudates and rhizodeposition in deeper layers could explain this trend (Wang et al. 2017). The negative relationship between the POXC/SOC ratio and SOC concentrations nevertheless suggests a methodological bias (Pulleman et al. 2021). Because the oxidation reaction is not controlled, soils with high levels of SOC tend to have proportionally less labile carbon than soils with lower levels of SOC, when using a fixed soil mass (Calderon et al. 2017; Pulleman et al. 2021). An overestimation of labile carbon in least carbon-rich soils and an underestimation in most carbon-rich soils relating to the method are likely implied in the absence of depth-trend for $\mathrm{POXC} / \mathrm{SOC}$ ratio in the present study. Relationships between POXC and SOC as well as POXC/SOC ratios were also shown to vary according to the site or climate (Culman et al. 2012; Duval et al. 2018; Ramírez et al. 2020). In our study, the POXC/SOC ratios decrease as the anthropogenic impacts on ecosystems decrease. Therefore, considering an identical SOC value, POXC was proportionally higher in avocado orchards or secondary forests than that in FFC and native forests. As previously explained, the bias induced by the POXC method could also be implied in such results. However, this trend could also result from differences in litterfall quality between agricultural and natural systems. Moreover, deforestation induces physical perturbation of the soil and increases breaks in soil aggregates (Islam and Weil 2000; Vedkamp et al. 2020). A higher proportion of POXC in SOC content in more anthropized soils could also be due to the destabilization of soil aggregates and/or to the desorption of organic compounds from oxides (Bailey et al. 2019). Tirol-Padre and Ladha (2004) did indeed highlight a decreasing relationship between POXC and clay+silt/SOC ratio, suggesting that POXC may also indicate the extent of physical protection of clay particles for oxidizable carbon in lignin. We cannot definitively explain this trend through our study, and future investigations will have to assess the different organic carbon fractions to understand the impact of land use on these 
soils. The POXC method does not, however, appear suitable to monitor the impact of land use on organic carbon in these carbon-rich soils.

\section{Land use impacts on the soil organic carbon}

While particularly high, mean SOC stocks assessed in $2000 \mathrm{Mg} \mathrm{ha}^{-1}$ ESM were, on average, lower in the soils of avocado orchards $\left(101.4 \pm 20.4 \mathrm{MgC} \mathrm{ha}^{-1}\right)$ than those in the soils of native forests $\left(138.3 \pm 23.6 \mathrm{MgC} \mathrm{ha}^{-1}\right)$. Carbon losses relating to land use were different in the different locations studied although, on average, the conversion of native forests to avocado plantations results in a relative loss of almost $30 \%$ of the initial SOC stock, which is in line with the results obtained by Don et al. (2011) on the conversion of primary forests to perennial crops in tropical climates. Soil carbon loss after deforestation can be accentuated when the precipitation rate is high (Guo and Gifford 2002; Powers et al. 2011), which is the case in Maré where annual rainfall is greater than $2500 \mathrm{~mm}$. Rapid SOC loss after deforestation could be attributed to the accumulation of particulate organic carbon, a carbon pool more sensitive to management practices than carbon associated with mineral fraction that could be rapidly mineralized (Fujisaki et al. 2017). SOC stocks from secondary forests were $20 \%$ lower than SOC stocks in native forests, displaying considerable differences in SOC contents in the 00-20-cm layer. In the past, part of the native forest was cleared to install herbaceous meadows because the straw was used to build traditional huts (Dubois 1984; Toussaint 2018). Over time, the anthropogenic grasslands would have been recolonized by exotic species, such as Schinus terebinthifolius, leading to the establishment of a secondary forest without a return to the initial native humid forest (Jaffré and Veillon 1987). Forest clearing, exportation of organic matter with straw harvests, and the establishment of an open-forested ecosystem less productive than the native forest have obviously led to a decrease in SOC concentrations.

Because of higher mean SOC stock in primary forests than in secondary forests before the change in land use, Don et al. (2011) suggested that the conversion of secondary forests to perennial crops barely seems to affect SOC stocks. However, in our study, the conversion of secondary forests to avocado plantations, which decreased the SOC stock by more than $30 \%$ in Tawaïnèdre, accentuates the older loss resulting from the conversion of native forest to secondary forest. Maré Island owns $40 \%$ of the avocado orchards in New Caledonia (DAVAR 2013), but this cultivation is not managed intensively. After forest clearing, the biomass is generally pulled out of the field and orchards are established. During the crop cycle, no fertilizer or amendment is used. Even considering that part of the productivity is returning to soil through litterfall, the continued export of organic matter and nutrients through avocado harvesting necessarily leads to a decrease in SOC stocks. Although avocado productivity is not at its maximum in these orchards, trees may produce between 10 and $30 \mathrm{~kg}$ of fruit per tree, leading to an annual exportation of fruit biomass of up to $7000 \mathrm{~kg}$ per hectare. Removal of nutrients during the fruit harvest can reach $300 \mathrm{gN}, 50 \mathrm{gP}$, and $500 \mathrm{gK}$ (per $100 \mathrm{~kg}$ fresh fruits) (Salazar-Garcia and Lazcano-Ferrat 2001). In this way, and without amendment management, soil nutrients decrease and negatively affect orchard and soil productivity as shown in other smallholding cultivation systems (Alfaia et al. 2004).

The role of management practices in SOC stocks in avocado orchards was especially highlighted with regard to the orchard in Atha. In this field, orchards were planted after the soil was tilled, leading to the SOC being mixed through the $30-\mathrm{cm}$ layer. Moreover, plantation ridges are permanently covered by a mulch of dead herbaceous material. The impact of this straw mulch on the soil is notably highlighted by the ${ }^{13} \mathrm{C}$ values of SOC. ${ }^{13} \mathrm{C}$ values of avocado leaves in different cultivars range from -32.62 to $-27.17 \%$, i.e., in the same range as other $\mathrm{C} 3$ vegetation (Acosta-Rangel et al. 2018). Thus, while the soils of other avocado orchards (Tawaïnèdre, Taodé) and forests have ${ }^{13} \mathrm{C}$ signatures relating to their dominant $\mathrm{C} 3$ vegetation, the $\mathrm{SOC}$ of the Atha orchard is enriched in ${ }^{13} \mathrm{C}$ because of $\mathrm{C} 4$ plant biomass inputs from straw mulch (Balesdent et al. 1987). The impact of the mulch decreased along the soil profile, as suggested by the depletion of ${ }^{13} \mathrm{C}$ in the soil of the Atha orchard compared to other orchards and forests for which ${ }^{13} \mathrm{C}$ enrichment of SOC was highlighted, as regularly shown in other forest soils (Balesdent et al. 1993; Rumpel and Kögel-Knaber 2011). Covering the soil of plantation lines has preserved and increased SOC content, as indicated by the higher SOC stock in this orchard compared to the neighboring secondary forest. Moreover, by increasing surface microbial activity, reducing environmental stress, and enhancing root health, organic mulches were shown to enhance fruit size and yields in avocado cultivation (Moore-Gordon et al. 1997; Lopèz et al. 2014; Wolstenholme et al. 1998). Covering soil is one of the bases of conservation agriculture because it maintains and improves soil health and has been suggested as a promising practice in smallholder farming in subtropical developing countries (Erenstein 2003). In Maré, adapting agricultural practices in orchards can preserve carbon in the soil after planting, and could also be a solution for increasing carbon storage in the soil of perennial crops.

Variations in SOC were smaller between FFC systems and native forests. The impact of FFC systems on SOC stocks and soil health are not consistent worldwide. While some studies have shown significant effects of FFC systems on soil microbiota, carbon content, and nutrient availability (Lintemani et al. 2020; Sarkar et al. 2015; Styger et al. 2007), others have identified little or no impact on soil characteristics and yields (Bruun et al. 2006; Kukla et al. 2019). In our study, SOC in FFC soils was only slightly lower than in the topsoil of native forests, i.e., to a depth of $10 \mathrm{~cm}$, but SOC stocks in the 2000 $\mathrm{MgC} \mathrm{ha}{ }^{-1}$ were not statistically different between these two 
types of land use. A decrease in SOC in the first centimeter of soil would partially result in biomass burning. At the soil surface, fire burns organic litter, but a part of the heat is radiated to the soil, and if temperatures reach between 100 and $200{ }^{\circ} \mathrm{C}$, volatile compounds, and a proportion of the SOC, notably lignin and hemicellulose, could be lost (GonzalesPérez et al. 2004). Moreover, fire can indirectly impact the SOM content by reducing aggregate stability (Thomaz 2018) and therefore its protection against decomposability (Abiven et al. 2009). During fires, gibbsite - one of the main minerals in these soils (Becquer et al. 2001) — is submitted to dehydroxylation (Ngole-Jeme 2019), depending on the duration and the temperature reached. For gibbsite, this phenomenon starts around $220^{\circ} \mathrm{C}$ and is complete around $350^{\circ} \mathrm{C}$, and it can be studied in infrared emission spectroscopy (Cornell and Schwertmann 2004; Kloprogge et al. 2002). We did not observe any modification of infrared spectra along the soil profile of FFC (data not shown), suggesting that soils experienced short-duration fires with low temperatures. Thus, the impact of fire on SOC transformation to charcoal would be low, as the charring process starts above $200{ }^{\circ} \mathrm{C}$ (GonzalesPérez et al. 2004).

In FFC systems, after the first year of yam cultivation, sweet potatoes and vegetables are cultivated for 1 or 2 years, and the field is then left fallow. In such systems, the duration of the fallow period as well as the type of agriculture, the frequency and intensity of burning, and the reforestation ability of the system appear to be key factors of soil recovery and of the return to the initial native floristic composition (Hauser and Norgrove 2013). Moreover, a recent study showed the important role played by forest understories with regard to SOC stocks during the fallow period (Sugihara et al. 2019). Although never studied in the Loyalty Islands, it appears that the FFC system, based on yam, traditionally used by Kanak people, would have a very low impact on SOC, particularly when it is compared to perennial and monocultural avocado cultivation. In the same way, in Brazilian Haplic Cambisol, Lintemani et al. (2020) showed that soil had a better quality in slash-and-burn agriculture than with the continuous cultivation of agricultural crops, or monoculture plantations.

\section{Perspectives with regard to addressing the challenges of soil organic carbon stocks on Maré: roles of traditional knowledge and changing agricultural practices}

While family farming based on FFC is a thousand-year-old practice, the planting of avocado orchards only dates back to the end of the last century. Our results clearly show that SOC stocks exhibit a particularly large decrease in these systems (except at the Atha site where different avocado practices are applied). Following the establishment of orchards, farmers were accompanied by technicians for only a few years with regard to managing their fields before being left on their own. Moreover, in the 1990s, a campaign to raise awareness of the vulnerability of the freshwater lens was launched. Fearing pollution of the main freshwater resource through the chemicals used in conventional agriculture, farmers stopped using them, probably thinking that orchards could be managed in the same way as their traditional cultivation system without any inputs. However, perennial crops, for which continuous exportation of matter leads to a decline in soil fertility, cannot be managed as FFC systems.

Because the intensity of pressures applied in FFC appears to be an important factor of the effects observed on soils, these systems would be especially well-adapted for small populations with abundant land, as is the case on Maré, where the demographic pressure is relatively low. The fallow period should increase after each cropping cycle, but instead, it tends to decrease worldwide (Styger et al. 2007). This is also the case on Maré Island due to society transformations leading to changes in agricultural practices and livelihoods. The population is relatively aging, as some of young people emigrate from Maré to the main island to study and work, either for a few years or permanently. This mobility limits the labor force available to access new plots in the forest and undoubtedly influences the choice of new plots to be cultivated. Consequently, farmers choose sites where vegetation is not particularly developed, i.e., forests that have been set aside for only a few years, leading to a shortening of the fallow period. Thus, in a study aimed at understanding the impact of fallow duration on soil fertility, we showed that SOM in the 00-20-cm layer tends to increase in the following sequence: short fallow $(10.48 \pm 0.28 \%)<$ long fallow $(11.38 \pm 1.54 \%)$ $<$ native forest $(12.65 \pm 1.16 \%)$ (unpublished data). While not significant, this slight but continuous decrease in SOM over time and excessively short periods between cropping cycles could endanger soil fertility, food security, and the quality of the freshwater lens on these small islands.

\section{Conclusion}

SOC stocks in the Gibbsic Ferralsol of Maré Island are particularly high, even in cultivated soils, ranging between 71.9 and 194.4 $\mathrm{MgC} \mathrm{ha}^{-1}$ in an equivalent soil mass of $2000 \mathrm{Mg} \mathrm{ha}^{-1}$. The mineralogical composition of these soils, especially the high content of aluminum oxides, could be involved in such results, but the key factors of organic carbon storage are still to be identified. Because of these high SOC concentrations, the POXC method is not appropriate for highlighting the impacts of land use on SOC in these soils, despite the fact that it is easy to implement for these small islands.

The traditional farming system practiced for hundreds of years, FFC, has few impacts on SOC stocks because the long fallow period after field cultivation facilitates recovery toward 
a situation close to the initial state of the soils. However, the evolution of Maré society could endanger SOC stocks. Indeed, while SOC stocks do not differ between FFC and native forests, they may be reduced in FFC soils in the future due to shortened fallow periods, and the impacts of this will have to be studied with regard to soil health and SOC stocks. Moreover, a shift from traditional farming toward perennial avocado cultivation has been encouraged despite reducing SOC stocks by up to $30 \%$, even when the orchards were established in place of secondary forests that had already suffered carbon losses compared to native forest soils.

In these soils, organic carbon storage could be limited by their low depth development, (40-cm depth on average). However, carbon storage in soils could be achieved to be consistent with 4per1000 objectives. Firstly, by applying adapted management practices in avocado orchards, SOC stocks could increase by more than $1 \mathrm{MgC}$ per ha per year, suggesting a recovery toward initial SOC stocks over a period of 20 years. Secondly, considering that secondary forests have $20 \mathrm{MgC} \mathrm{ha}^{-1}$ less than native forests, management policies would have to be adopted to improve the recovery of anthropized forests toward native forests, especially in light of the importance of healthy forest ecosystems for traditional farming in these tropical islands.

Total and cultivated areas in Maré, and more generally in the Loyalty Islands, represent an insignificant surface on a global scale. The increase in SOC stocks could nevertheless help reduce New Caledonia's carbon footprint on a regional scale and ensure the preservation of soils for the food requirements of these small, fragile territories.

Supplementary Information The online version contains supplementary material available at https://doi.org/10.1007/s10113-021-01814-x.

Acknowledgements The authors are grateful to the farmers of Maré Island for allowing them access and sample their fields, both in avocado orchards and FFC plots. We also offer our warmest thanks to the staff of the "Laboratoire des Moyen Analytiques", IRD Nouméa. We are also grateful to the editors and two anonymous reviewers for their valuable comments.

Open Access This article is licensed under a Creative Commons Attribution 4.0 International License, which permits use, sharing, adaptation, distribution and reproduction in any medium or format, as long as you give appropriate credit to the original author(s) and the source, provide a link to the Creative Commons licence, and indicate if changes were made. The images or other third party material in this article are included in the article's Creative Commons licence, unless indicated otherwise in a credit line to the material. If material is not included in the article's Creative Commons licence and your intended use is not permitted by statutory regulation or exceeds the permitted use, you will need to obtain permission directly from the copyright holder. To view a copy of this licence, visit http://creativecommons.org/licenses/by/4.0/.

\section{References}

Abiven S, Menasseri S, Chenu C (2009) The effect of organic inputs over time on soil aggregate stability - a literature analysis. Soil Biol Biochem 41:1-12. https://doi.org/10.1016/j.soilbio.2008.09.015

Acosta-Rangel A, Avila-Lovera E, De Guzman ME, Torres L, Haro R et al (2018) Evaluation of leaf carbon isotopes and functional traits in avocado reveals water-use efficient cultivars. Agric Ecosyst Environ 263:60-66. https://doi.org/10.1016/j.agee.2018.04.021

Alfaia SS, Ribeiro GA, Nobre AD, Luizão RC, Luizão FJ (2004) Evaluation of soil fertility in smallholder agroforestry systems and pastures in western Amazonia. Agric Ecosyst Environ 102:409414. https://doi.org/10.1016/j.agee.2003.08.011

Awale R, Emeson MA, Machado S (2017) Soil organic carbon pools as early indicators for soil organic matter stock changes under different tillage practices in inland Pacific northwest. Front Ecol Evol 5:96. https://doi.org/10.3389/fevo.2017.00096

Bailey VL, Pries CH, Lajtha K (2019) What do we know about soil carbon destabilization? Environ Res Lett. https://doi.org/10.1088/ 1748-9326/ab2c11

Balesdent J, Mariotti A, Guillet B (1987) Natural ${ }^{13} \mathrm{C}$ abundance as a tracer for studies of soil organic matter dynamics. Soil Biol Biochem 19:25-30. https://doi.org/10.1016/0038-0717(87)90120-9

Balesdent J, Girardin C, Mariotti A (1993) Site-related $\delta^{13} \mathrm{C}$ of tree leaves and soil organic matter in a temperate forest. Ecology 74:17131721. https://doi.org/10.2307/1939930

Barrau J (1956) L'agriculture vivrière autochtone de la NouvelleCalédonie. Nouméa, Commission du Pacifique Sud

Becquer T, Bourdon E, Nigote W (1993) Contribution à l'étude des sols de Maré : les sols des centres d'appuis au développement agricole de Tawaïnèdre et Taodé : 1. Caractérisation morphologique et cartographie des épaisseurs de sols. Nouméa : ORSTOM, (17), 37 p. multigr. (Sciences de la Vie. Agropédologie. Conventions ; 17)

Becquer T, Pétard J, Duwig C, Bourdon E, Moreau R et al (2001) Mineralogical, chemical and charge properties of Geric Ferralsols from New Caledonia. Geoderma 103:291-306. https://doi.org/10. 1016/S0016-7061(01)00045-3

Bélières J-F, Bonnal P, Bosc P-M (coord.), Losch B, Marzin J, Sourisseau J-M, 2014. Les agricultures familiales du monde. Définitions, contributions et politiques publiques. Paris : Agence française de développement (collection « À savoir »).

Bongiorno G, BünemannEK OCU, Meier J, Gort G, Comans R et al (2019) Sensitivity of labile carbon fractions to tillage and organic matter management and their potential as comprehensive soil quality indicators across pedoclimatic conditions in Europe. Ecol Indic 99: 38-50. https://doi.org/10.1016/j.ecolind.2018.12.008

Bouard S, Apithy L, Guyard S (2018) Family farming in contemporary Kanak society, in Bosc P-M, Sourisseau J-M, Bonnal P, Gasselin P, Valette E, Bélières J-F (Eds.), Diversity of family farming around the world, existence, transformations and possible futures of family farms, Quae Springer International Publishing, https://doi.org/10. 1007/978-3-319-77535-7

Bruun TB, Mertz O, Elberling B (2006) Linking yields of upland rice in shifting cultivation to fallow length and soil properties. Agric Ecosyst Environ 113:139-149. https://doi.org/10.1016/j.agee.2005. 09.012

Calderon FJ, Culman S, Six J, Franzluebbers AJ, Schipanski M et al (2017) Quantification of soil permanganate oxidizable C (POXC) using infrared spectroscopy. Soil Sci Soc Am J 81:277-288. https:// doi.org/10.2136/sssaj2016.07.0216

Cornell RM and Schwertmann U (2004) The iron oxides: structure, properties, reactions, occurrences and uses, 2nd ed.;Wiley-VCH Verlag GmbH \& Co. KGaA:Weinheim, Germany 
Culman SW, DuPont ST, Glover JD, Buckley DH, Fick GW et al (2010) Long-term impacts of high-input annual cropping and unfertilized perennial grass production on soil properties and belowground food webs in Kansas, USA. Agric Ecosyst Environ 137:13-24. https:// doi.org/10.1016/j.agee.2009.11.008

Culman SW, Snapp SS, Freeman MA, Schipanski ME, Beniston J et al (2012) Permanganate oxidizable carbon reflects a processed soil fraction that is sensitive to management. Soil Sci Soc Am J 76: 494-504. https://doi.org/10.2136/sssaj2011.0286

Davar (2013) L'agriculture Calédonienne de 2004 à 2013. Pp.102

Demisie W, Liu Z, Zhang M (2014) Effect of biochar on carbon fractions and enzyme activity of red soil. Catena 121:214-221. https://doi. org/10.1016/j.catena.2014.05.020

Don A, Schumacher J, Freibauer A (2011) Impact of tropical land-use change on soil organic carbon stocks - a meta-analysis. Glob Chang Biol 17:1658-1670. https://doi.org/10.1111/j.1365-2486.2010. 02336.x

Dubois M-J (1984) Gens de Maré, Nouvelle-Calédonie. Paris, Antrhopos, Pp.376

Duval ME, Galantini JA, Martínez JM, Limbozzi F (2018) Labile soil organic carbon for assessing soil quality: influence of management practices and edaphic conditions. Catena 171:316-326. https://doi. org/10.1016/j.catena.2018.07.023

Duwig C (1998) Étude des transferts d'eau et de nitrate dans les sols ferrallitiques de Maré (Nouvelle-Calédonie) : risques de pollution des lentilles d'eau douce. Thèse de Doctorat, Grenoble 1. Pp.189

Erenstein O (2003) Smallholder conservation farming in the tropics and sub-tropics: a guide to the development and dissemination of mulching with crop residues and cover crops. Agric Ecosyst Environ 100:17-37. https://doi.org/10.1016/S0167-8809(03) 00150-6

FAO (2014) The state of food and agriculture 2014: innovation in family farming. FAO, Rome

Fritsch E (2012) Les sols. In: Bonvallot J, Gay JC, Habert E (eds) Atlas de la Nouvelle-Calédonie. Marseille, IRD Editions, pp 73-76

Fujisaki K, Perrin A.-S, Garric B, Balesdent J, Brossard M (2017) Soil organic carbon changes after deforestation and agrosystem establishment in Amazonia: an assessment by diachronic approach. Agric Ecosyst Environ 245, 63-73. https://doi.org/10.1016/j.agee. 2017.05.011

Gonzales-Pérez J-A, Gonzales-Vila FJ, Almendros G, Knicker H (2004) The effect of fire on soil organic matter- a review. Environ Int 30: 855-870. https://doi.org/10.1016/j.envint.2004.02.003

Graeub BE, Chappell MJ, Wittman H, Ledermann S, Kerr RB, GemmillHerren B (2016) The state of family farms in the world. World Dev 87:1-15. https://doi.org/10.1016/j.worlddev.2015.05.012

Guo LB, Gifford RM (2002) Soil carbon stocks and land use change: a meta analysis. Glob Chang Biol 8:345-360. https://doi.org/10.1046/ j.1354-1013.2002.00486.x

Guyard S, Apithy L, Bouard S, Sourisseau J-M, Passouant M et al (2014) L'agriculture des tribus en Nouvelle-Calédonie Résultats d'une enquête de 2010 sur la place et les fonctions de l'agriculture, l'élevage, la pêche et la chasse pour les groupes domestiques résidant en tribu. IAC/CIRAD, Pouembout

Hauser S and Norgrove L (2013) Slash-and-burn agriculture, effects of. In: Levin SA (ed.) Encyclopedia of biodiversity, second edition, Volume 6, pp. 551-562. Waltham, MA: Academic Press

Haynes RJ (2005) Labile organic matter fractions as central components of the quality of agricultural soils: an overview. Adv Agron 85:221268. https://doi.org/10.1016/S0065-2113(04)85005-3

Hurisso TT, Culman SW, Horwath WR, Wade J, Cass D et al (2016) Comparison of permanganate-oxidizable carbon and mineralizable carbon for assessment of organic matter stabilization and mineralization. Soil Sci Soc Am J 80:1352-1364. https://doi.org/10.2136/ sssaj2016.04.0106

IPCC (2019) Summary for policymakers. In: Climate change and land: an IPCC special report on climate change, desertification, land degradation, sustainable land management, food security, and greenhouse gas fluxes in terrestrial ecosystems [Shukla PR, Skea J, Calvo Buendia E, Masson-Delmotte V, Pörtner H-O, Roberts DC, Zhai P, Slade R, Connors S, van Diemen R, Ferrat M, Haughey E, Luz S, Neogi S, Pathak M, Petzold J, Portugal Pereira J, Vyas P, Huntley E, Kissick K, Belkacemi M, Malley J (eds.). In press

Islam KR, Weil RR (2000) Land use effects on soil quality in a tropical forest ecosystem of Bangladesh. Agric Ecosyst Environ 79:9-16. https://doi.org/10.1016/S0167-8809(99)00145-0

Jaffré T and Veillon J-M (1987) Étude des jachères et premiers aperçus sur la succession secondaire à Lifou (Iles Loyauté - NouvelleCalédonie). Nouméa : ORSTOM, (1), 28 p. multigr. (Sciences de la Vie. Botanique. Rapports Scientifiques et Techniques ; 1)

Jensen JL, Schjonning P, Watts CW, Christensen BT, Obour PB, Munkholm LJ (2020) Soil degradation and recovery - changes in organic matter fractions and structural stability. Geoderma 364: 114181. https://doi.org/10.1016/j.geoderma.2020.114181

Kleber M, Sollins P, Sutton R (2007) A conceptual model of organomineral interactions in soils: self-assembly of organic molecular fragments into zonal structures on mineral surfaces. Biogeochemistry 85:9-24. https://doi.org/10.1007/s10533-0079103-5

Kloprogge JT, Druan HD, Frost RL (2002) Thermal decomposition of bauxite minerals: infrared emission spectroscopy of gibbsite, boehmite and diaspore. J Mater Sci 37:1121-1129. https://doi.org/ 10.1023/A: 1014303119055

Kukla J, Whitfeld T, Cajthaml T, Baldrian P, Veselá-Šimáčková H et al (2019) The effect of traditional slash-and-burn agriculture on soil organic matter, nutrient content, and microbiota in tropical ecosystems of Papua New Guinea. Land Degrad Dev 30:166-177. https:// doi.org/10.1002/ldr.3203

Lal R (2004) Soil carbon sequestration impacts on global climate change and food security. Science 304:1623-1627. https://doi.org/10.1126/ science. 1097396

Lal R (2016) Soil health and carbon management. Food Energy Secur 5: 212-222. https://doi.org/10.1002/fes3.96

Lal R (2020) Food security impacts of the "4 per Thousand" initiative. Geoderma 374:114427. https://doi.org/10.1016/j.geoderma.2020. 114427

Latham M and Mercky P (1981) Étude des sols des Iles Loyauté. Carte des sols et carte d'aptitude culturale et forestière Office de la Recherche Scientifique et Technique Outre-Mer: 99

Le Quéré C, AndrewRM FP, Sitch S, Hauck J, Pongratz J et al (2018) Global carbon budget 2018. Earth Syst Sci Data 10:2141-2194. https://doi.org/10.5194/essd-10-2141-2018

Lintemani MG, Loss A, Mendes CS, Fantini AC (2020) Long fallows allow soil regeneration in slash-and burn agriculture. J Sci Food Agric 100:1142-1154. https://doi.org/10.1002/jsfa.10123

Lopez R, Burgos P, Hermoso JM, Hormaza JI, Gonzales-Fernandez J-J (2014) Long term changes in soil properties and enzyme activities after almond shell mulching in avocado organic production. Soil Tillage Res 143:155-163. https://doi.org/10.1016/j.still.2014.06. 004

Mathieu JA, Hatté C, Balesdent J, Parent É (2015) Deep soil carbon dynamics are driven more by soil type than by climate: a worldwide meta-analysis of radiocarbon profiles. Glob Chang Biol 21:42784292. https://doi.org/10.1111/gcb.13012 
Melero S, Panettieri M, Madejón E, Macpherson HG, Moreno F et al (2011) Implementation of chiselling and mouldboard ploughing in soil after 8 years of no-till management in SW, Spain: effect on soil quality. Soil Tillage Res 112:107-113. https://doi.org/10.1016/j. still.2010.12.001

Minasny B, Malone B, McBratney AB, Angers DA, Arrouays D et al (2017) Soil carbon 4 per mille. Geoderma 292:59-86. https://doi. org/10.1016/j.geoderma.2017.01.002

Moni C, Chabbi A, Nunan N, Rumpel C, Chenu C (2010) Spatial dependance of organic carbon-metal relationships - a multi-scale statistical analysis, from horizon to field. Geoderma 158:120-127. https:// doi.org/10.1016/j.geoderma.2010.04.014

Moore-Gordon C, Cowan AK, Wolstenholme BN (1997) Mulching of avocado orchards to increase Hass yield and fruit size and boost financial rewards a three season summary of research findings. South African Avocado Growers' Association Yearbook 20:46-49

Morat P, Jaffré T, Veillon J-M (2001) The flora of New Caledonia's calcareous substrates. Adansonia 23:109-127

Morrow JG, Huggins DR, Carpenter-Boggs LA, Reganold JP (2016) Evaluating measures to assess soil health in long-term agroecosystem trials. Soil Sci Soc Am J 80:450-462. https://doi. org/10.2136/sssaj2015.08.0308

Ngole-Jeme V (2019) Fire-induced changes in soil and implications on soil sorption capacity and remediation methods. Appl Sci 9:3447. https://doi.org/10.3390/app9173447

Paustian K, Lehmann J, Ogle S, Reay D, Robertson GP et al (2016) Climate-smart soils. Nature 532:49-57. https://doi.org/10.1038/ nature 17174

Powers JS, Corred MD, Twine TE, Veldkamp E (2011) Geographic bias of field observations of soil carbon stocks with tropical land-use changes precludes spatial extrapolation. Proc Natl Acad Sci 108: 6318-6322. https://doi.org/10.1073/pnas.1016774108

Pulleman M, Wills S, Creamer R, Dick R, Ferguson R, Hooper D, Williams C, Margenot AJ (2021) Soil mass and grind size used for sample homogenization strongly affect permanganate-oxidizable carbon (POXC) values, with implications for its use as a national soil health indicator. Geoderma 383:114742. https://doi.org/10. 1016/j.geoderma.2020.114742

Ramírez PB, Calderón FJ, Fonte SJ, Santibáñez F, Bonilla CA (2020) Spectral responses to labile organic carbon fractions as useful soil quality indicators across a climatic gradient. Ecol Indic 111:106042. https://doi.org/10.1016/j.ecolind.2019.106042

Rumpel C, Kögel-Knaber I (2011) Deep soil organic matter - a key but poorly understood component of terrestrial C cycle. Plant Soil 338: 143-158. https://doi.org/10.1007/s11104-010-0391-5

Rumpel C, Amiraslani F, Koutika L-S, Smith P, Whitehead D et al (2018) Put more carbon in soils to meet Paris climate pledges. Nature 564: 32-34. https://doi.org/10.1038/d41586-018-07587-4

Rumpel C, Amiraslani F, Chenu C, Cardenas M, Kaonga M et al (2019) The 4p1000 initiative: opportunities, limitations and challenges for implementing soil organic carbon sequestration as a sustainable development strategy. AMBIO a journal of the human Environment 49. https://doi.org/10.1007/s13280-019-01165-2

Salazar-Garcia S, Lazcano-Ferrat I (2001) Identifying fruit mineral removal differences in four avocado cultivars. Better Crops Int 15: 28-31. https://doi.org/10.1080/01904167.2019.1659322

Sand C, Bole J, Ouetcho A (2000) Les sociétés pré-européennes de Nouvelle-Calédonie et leur transformation historique. L'apport de l'archéologie In : En pays kanak : Ethnologie, linguistique, archéologie, histoire de la Nouvelle-Calédonie. (Ed) Maison des sciences de 1'Homme. https://doi.org/10.4000/books.editionsmsh. 2782
Sarkar D, Bungbungcha Meitei C, Baishya LK, Das A, Ghosh S et al (2015) Potential of fallow chronosequence in shifting cultivation to conserve soil organic carbon in northeast India. Catena 135:321327. https://doi.org/10.1016/j.catena.2015.08.012

Schlesinger WH, Andrews JA (2000) Soil respiration and the global carbon cycle. Biogeochemistry 48:7-20. https://doi.org/10.1023/A: 1006247623877

Skjemstad JO, Swift RS, McGowan JA (2006) Comparison of the particulate organic carbon and permanganate oxidation methods for estimating labile soil organic carbon. Aust J Soil Res 44:255-263. https://doi.org/10.1071/SR9960413

Smith KA, Ball T, Conen F, Dobbie KE, Massheder J et al (2018) Exchange of greenhouse gases between soil and atmosphere: interactions of soil physical factors and biological processes. Eur J Soil Sci 69:10-20. https://doi.org/10.1111/ejss.12539

Styger E, Rakotondramasy HM, Pfeffer MJ, Fernandes ECM, Bates DM (2007) Influence of slash-and burn farming practices on fallow succession and land degradation in the rainforest region of Madagascar. Agric Ecosyst Environ 119:257-269. https://doi.org/10.1016/j.agee. 2006.07.012

Sugihara S, Shibata M, Mvondo Ze AD, Tanaka H, Kosaki T et al (2019) Forest understories controlled the soil organic carbon stock during the fallow period in African tropical forest: a 13C analysis. Sci Rep 9:9835. https://doi.org/10.1038/s41598-019-46406-2

Tercinier G (1954) Matière organique, humus, et sols de la côte ouest de la Nouvelle-Calédonie. Revue Agricole de la Nouvelle Calédonie et Dépendances 1-2:6-14

Tercinier G (1963) Les sols de la Nouvelle-Calédonie. Cahiers ORSTOM. Série Pédologie, 1963, (1), 53 p. ISSN 0029-7259

Tercinier G (1971) Contribution à la connaissance des phénomènes de bauxitisation et d'allitisation : les sols des karsts d'atolls surélevés du Sud-Ouest Pacifique. Cahiers ORSTOM. Série Pédologie 9(3): 307-334 ISSN 0029-7259

Tirol-Padre A, Ladha JK (2004) Assessing the reliability of permanganate-oxidizable carbon as an index of soil labile carbon. Soil Sci Soc Am J 68:969-978. https://doi.org/10.2136/sssaj2004. 9690

Thomaz EL (2018) Dynamics of aggregate stability in slash-and-burn system: relaxation time, decay, and resilience. Soil Tillage Res 178:50-54. https://doi.org/10.1016/j.still.2017.12.017

Toussaint M (2018) "L'épreuve du feu. Politiques de la nature, savoirs, feux de brousse et décolonisation en Nouvelle-Calédonie." PhD thesis. École des Hautes Études en Sciences Sociales (EHESS), Marseille

Vedkamp E, Schmidt E, Powers JS, Corre MD (2020) Deforestation and reforestation impacts on soil in the tropics. Nature Rev Earth Environ 1:590-605. https://doi.org/10.1038/s43017-020-0091-5

Wade J, Maltais-Landry G, Lucas DE, Bongiorno G, Bowles TM et al (2020) Assessing the sensitivity and repeatability of permanganate oxidizable carbon as a soil health metric: An interlab comparison across soils. Geoderma 366:114235. https://doi.org/10.1016/j. geoderma.2020.114235

Walkley A, Black IA (1934) An examination of Degtjareff method for determining soil organic matter, and proposed modification of the chromic acid titration method. Soil Sci 37:29-38. https://doi.org/10. 1097/00010694-193401000-00003

Wang F, Weil RR, Nan X (2017) Total and permanganate-oxidizable organic carbon in the corn rooting zone of US coastal plain soils as affected by forage radish cover crops and $\mathrm{N}$ fertilizer. Soil Tillage Res 165:247-257. https://doi.org/10.1016/j.still.2016.08.022

Weil RR, Islam KR, Stine MA, Gruver JB, Samson-Liebig SE (2003) Estimating active carbon for soil quality assessment: a simplified 
method for laboratory and field use. Am J Altern Agric 18:3-17. https://doi.org/10.1079/AJAA200228

Wendt JW, Hauser S (2013) An equivalent soil mass procedure for monitoring soil organic carbon in multiple soil layers. Eur J Soil Sci 64: 58-65. https://doi.org/10.1111/ejss.12002

Wiesmeier M, Urbanski L, Hobley E, Lang B, von Lützow M et al (2019) Soil organic carbon storage as a key function of soils - a review of drivers and indicators at various scales. Geoderma 333:149-162. https://doi.org/10.1016/j.geoderma.2018.07.026
Wolstenholme BN, Moore-Gordon CS, Cowan AK (1998) Mulching of avocado orchards: quo vadis? South African Avocado Growers' Association Yearbook 1998. 21:26-28

Fontaine S, Barot S, Barré P, Bdioui N, Mary B et al (2007) Stability of organic carbon in deep soil layers controlled by fresh carbon supply. Nature 450(7167):277-280. https://doi.org/10.1038/nature06275

Publisher's note Springer Nature remains neutral with regard to jurisdictional claims in published maps and institutional affiliations. 